\title{
5 Alpha Steroid Reductase 2 Deficiency
}

National Cancer Institute

\section{Source}

National Cancer Institute. 5 Alpha Steroid Reductase 2 Deficiency. NCI Thesaurus. Code C98699.

An autosomal recessive inherited disorder caused by mutations in the SRD5A2 gene. It is characterized by deficiency of the enzyme steroid 5-alpha reductase 2 that catalyzes the conversion of testosterone to dihydrotestosterone. It results in disruption of the formation of male genitalia. Patients present with pseudohermaphroditism. 